\title{
Could Regional Trade Integration be a Building Block for Global Governance of Trade?
}

\section{Ludmila Štěrbová*}

International relations - as the branch of political science that is concerned with the foreign affairs of and relations among countries - considers the states' sovereignty as a basis for improvement of worldwide peaceful partnership among states. Based on state sovereignty, governments "protect" the policy space which they consider to be a necessary presumption for further national economic and social development. The possibility of global governance, in whichever field of activities, is related to the governments' ability to give a part of the domestic policy space (it means a part of their sovereignty) in favour of the common good and common long-term interests and perspectives. This is the main dialectical question of global governance, including the governance of international trade. The dilemma or mutual supportiveness of regionalism and multilateralism should be analyzed in relation to it.

Global governance theory develops approaches, which attempt to find a workable structure(s) in which the global tendencies are reflected. In the most recent period, the ideas of prosperity of regional integration - as a basis for global governance - are widely supported. According to one stream within these theories, regional governance could be extended to a global one, after the benefits have been proved within a small scale. The other stream argues that only negotiations among regional groups lead towards global governance. The ground for this idea is to restrict the number of actors of international relations and, as a result, to simplify the complexity of negotiations and to facilitate their positive outcomes. In this article, I try to show which weaknesses have these ideas in the framework of international trade, which is an important part of international relations.

\section{Dialectics of global trade governance}

Global trade governance is linked to the multilateral trading system, which is embodied into the structure of the World Trade Organization (WTO) agreements and principles. Having analyzed the above mentioned ideas on a smooth conversion of regionalism into multilateralism in the context of international trade, I came to the conclusion that neither one of them could respond to the main dialectical question of global trade governance. Neither one of them proved, moreover, to be beneficial for global trade or for actors participating in it. Namely the first assumption does not support attempts to develop global trade governance with benefits for all, including marginal economies. Regional Trade Agreements (RTAs) on a more preferential reciprocal trade treatment among parties conversely create obstacles to trade with other partners and these barriers proved in some cases to be

\footnotetext{
This article has been worked out within the framework of the Czech Science Agency Project „, Regionalism and Multilateralism: Foundations of the New World Trade Order?" No. 402/07/0253.

* Ing. Ludmila Štěrbová, CSc. - lecturer; Department of International Trade, Fakulty of International Relations, University of Economics, Prague, nám. W. Churchilla 4, 13067 Praha 3, Czech Republic; <sterbovl@vse.cz>.
} 
insurmountable. The global blur of existing RTAs leads governments to preserving a large policy space without any specific domestic purpose, which could be used "in exchange" with bilateral trade partners in the framework of eventual future regional preferential agreements.

Despite some attempts to introduce the idea of region-to-region negotiations into the discussion on global trade rules and trade liberalization, the practice did not prove them to be successful. A stumbling block for the implementation and further elaboration of the mentioned theories is the sovereignty of individual states. The principle of sovereignty, which was introduced into international relations in 1648 after the signature of treaties referred as Peace of Westphalia, is a keystone from which the state governments derive their legitimacy (besides the diplomatic recognition by other states). Governments support their single interests by establishing alliances of like-minded countries, but once the alliance diverges on other components, state sovereignty prevails and governments are not ready to sacrifice any trade aspects to benefit for other regional partners.

The regions could not be considered as an example of "small" worlds where trade problems are solved first and after then these consolidated entities could advance to the negotiations of any global trade governance. The regions have different level of economic and social development and different concepts of trade governance. Trade rules established within separate regions could differ substantially and it could be impossible to merge them together in region-to-region negotiations.

If we do not want to abandon the idea of global trade governance, we should analyze the pre-requisites towards it without any partial or temporal steps reflected in regional approaches. I find that the most important condition of multilateral trading system is the confinement of the individual governments' policy space. The arguments supporting my opinion are to be found through the historical development of the multilateral trading system, whose establishment after the World War II was seen as one of the best possibilities for a quick and overall post war economic development. The idea of global trade governance was based on the states' sovereignty, part of which was given-up by states in favour of the common good, and on the enforcement of rules through challenges from other trading partners. One very important issue in this regard was how large a part of the mentioned state sovereignty should have been abandoned, in other words, how large was the safe policy space that should have remained at the disposal of a sovereign state in order to pursue efficiently all its policy objectives.

Although the multilateral trading system started its development without any response to this question and the arguments on policy space from the U.S. Congress did not allow the creation of the International Trade Organization and catapulted the effort in Havana, the system attracted more and more governments, which found it to be effective for pursuing their trade interests. As the development of RTAs is a feature of only the last two decades, we should state that multilateralism prevailed in the post-war trade development and that the strongest economies of the world benefited from it.

Global trade governance relied for almost 50 years only on the provisional General Agreement on Tariffs and Trade (GATT). The question on policy space, more exactly the question of whether or not policy space is a necessary component of any trade agreement on trade rules and of trade liberalization commitments, has not yet been answered. It is without any doubt that trade agreements limit de jure the policy space and the real governments' degrees of freedom. This concept has been known since the first two countries signed the first trade agreement. On the other hand, if a government disposes of a large policy space, it is 
tempted to restrict fair trade, to maintain or to create restrictions without adjusting its industry to competitive conditions.

The issue of policy space has become more pertinent in the ongoing Doha multilateral trade negotiations of the World Trade Organization, during which many developing countries expressed their fears not to dispose of adequate tools to address the policy objectives they have or they might have in the future, and to lose in reality their ability to act. Some scholars, including Alan Winters from the University of Sussex, argue that nowadays the preservation of any domestic policy space is no longer needed. Governments want to have the ability to vary tariff rates but the evidence that increasing tariffs provides for viable industries is very small. Similarly, there is not very much evidence that subsidies could help domestic industry in the medium- and long-terms. However, both tariffs and subsidies and other restrictions and supports open a space for lobbying from political interests and political pressure (WTO, 2007).

Strong trade rules, without preferences or exemptions for any trade partner, could help governments to resist pressure and to choose the policies that maximize the welfare of the poor (Ricardo Melendez-Ortiz, at WTO, 2007). This means without preferences and exemptions, including those offered to partners of RTAs, as the variety of these exemptions, even legal, undermines transparency of the trade rules and opens subsequently space for negative impacts of lobbying and political pressure. It is necessary to acknowledge, moreover, that the RTAs are not concluded only for the sake of trade and that in them the broader public policy objectives prevail. As such, the regional trade agreements are tools of strategic trade policy, which try to reflect imperfect competition, and could not contribute efficiently to global trade governance based on "common sharing" of a part of government's sovereignty.

\section{Interference of multilateral trading system and domestic policies}

The current globalization tendencies made the analysis of the main dialectical question of global trade governance more crucial and acute for the prosperity of international trade than it was historically. Since the multilateral trade negotiations during the Uruguay Round, the domestic policies considerably entered into the negotiating process. The trade negotiations intervene into domestic policies, which relations to the trade has been historically considered only absent or very weak, such as protection and enforcement of intellectual property rights, government procurements, administrative procedures, investment, competition, legislation for services providers, environment, etc.

In the period of the provisional GATT, until 1980s, the participants of multilateral trade negotiations concentrated on the liberalization of market access - border and related measures, as tariffs, quotas, some non-tariff barriers, technical and hygienic norms, partially antidumping rules and rules of origin. Little intrusion into domestic policy occurred. As a result of the Uruguay Round of negotiations, market access liberalization accelerated, the number of participants in the system increased by $50 \%$ and various issues of domestic policy were concerned.

The current round of multilateral negotiations, the Doha Development Agenda (DDA) - if concluded successfully - will have a larger impact on domestic policies, like services, agricultural and all other domestic subsidies, rules for regional trade agreements, antidumping rules, environment, trade facilitation procedures, etc. Market access 
liberalisation will not be as progressive as before and it will probably be short in touching sensitive issues for developed countries, like antidumping, investment measures, government procurement, tariffs peaks, rules of origin, standards, public health, etc.

On the other hand, policy makers are forced to engage in an interactive double-edged negotiating process in which deals at the international level change the character of domestic constraints, while the movement of domestic politics opens up new possibilities for international accords (Hastedt, 1999, p. 276). Negotiators are simultaneously occupying positions in two linked games: one to conclude an international agreement, the other to secure domestic approval for it.

As a consequence of the deep interference, trade negotiations are very frequently discussed at domestic political scenes, where the opinion of policy leaders regarding the trade governance is subject to an electoral play, as for instance in the USA. The recent example could be an assessment of multilateral trade negotiations and liberalization by Senator Hillary Clinton, when she said that if elected US president she would "take a hard look at the Doha Round" before deciding whether to pursue it. "I am concerned by provisions that would prevent countries from enforcing stronger environmental and safety rules under the WTO. I want to have a more comprehensive and thoughtful trade policy for the $21^{\text {st }}$ century. There is nothing protectionist about this. It is a responsible course", she added. At the same, she has called for a full review of all trade deals, including NAFTA, and has also attacked trade agreements that do not include provisions to protect workers and enforce higher environmental standards (Financial Times, 2007).

Another example of the complexity of a trade strategy and of the interaction among multilateral trading system, RTAs, domestic policies and domestic politic scene is the U.S. House of Representatives approval of 8 November 2007 for a Free Trade Agreement (FTA/FTAs) with Peru. U.S. Democrats had always broadly opposed the George W. Bush administration's trade agenda and namely the FTAs with developing countries outside the Middle East. The FTA with Peru, however, received crucial support from almost half of Democrats, who joined Republicans to ensure its passage. The Democratic leadership had campaigned for the Peru deal, as they did not want to be viewed as an anti-trade party. Democrats departed from their past oppositon to trade agreements once they successfully pushed for re-negotiation FTAs in order to strengthen provisions on labour and environmental protection as well as access to medicines. The Democrats argue that the FTA with Peru will not only open new markets for American goods and services, but for the first time the enforceable standards for workers and stronger environmental protections are included in the text of the agreement. According to some analysis in the New York Times, Democratic backing for the deal has been bolstered by campaign contributions from industries that benefit from opening up foreign markets. The party's rising political fortunes have earned its donations from firms in sectors such as high-tech manufacturing and financial services. Nevertheless, more than half of Democrats voted against, expressing fears of trade liberalization, as for example former North Carolina Senator John Edwards, whose state has seen significant job losses in the textile industry. Critics of the deal expressed also concern that Peru would not enforce its environmental and labour standards. The deep split among Democrats extends also to the party's leading presidential candidates, as Senators Hillary Clinton (New York) and Barack Obama (Illinois) support the agreement.

Behind the recent voting for the FTA with Peru is the historical challenge of trade liberalization and its consequences, which parties try to solve in favor of their constituency. Democrats attribute partially the party's success in Congressional elections last year to the more protectionist policies, which met concerns of voters afraid of losing jobs to cheaper 
overseas competitors. At the global scale, U.S. Democrats' angst over trade is one of many substantial obstacles to concluding the faltering Doha Round of talks at the WTO.

Although leading Republican presidential candidates have not been openly critical of trade agreements, six out of ten Republicans believed that free trade had been bad for the U.S. and than tougher limits on foreign imports shall be favored. Opinion polls suggest that supporters of both parties in the US are increasingly skeptical about the benefits of open trade (Bridges Weekly, 2007). It is a reason why - in the situation of ongoing multilateral negotiations on reduction of agricultural supports - the Farm bill has been drafted without changing anything on domestic agricultural subsidization, and why the Congress is currently working on legislation to greatly expand governmental assistance to workers who lose their jobs as a result of imports or outsourcing.

Politics, even being skeptical on the free trade, could not however avoid all discussions on trade agreements, as within the producers and consumers there are always groups, which lobby for expansion on foreign markets. In this situation it is more feasible for any government to propose only bilateral deals, which scope is limited and by which some industry could be satisfied without injuring the others. For instance, the European Communities and the USA farm subsidies are not included into their bilateral trade agreements. Developed countries use often the FTAs to pursue obligations related to intellectual property, health, labor, environment, etc.

The mentioned reasons for preferring regional trade governance to the global one are not, however, approved. General principles of the multilateral trading system embody a lot of flexibility, which could be efficiently used for a development of domestic industry. In the area of tariffs, there is always a huge flexible gap between bound and applied tariffs for both industrial as well as agricultural products. Moreover, governments always have the right to renegotiate tariffs or even to introduce certain emergency measures if there is any danger for the economy - difficulties in the balance of payment, subsidised import, its surges, anticompetitive prices, etc. WTO members benefit also from waivers and decisions made in their favour, and could propose others based on their economic situation. The new round of negotiations provides for an extension of these flexibilities. In agricultural liberalization, for instance, developing countries will be able to slate for gentle or no tariff cuts in order to address food and livelihood security and rural development concerns. The structure of a special safeguard mechanism, with the aim to afford developing countries a measure of protection from import surges, is also to be addressed. The same goes for agriculture subsidization, which is actually allowed in very many forms.

It is clear that interference of multilateral trading system and domestic policies could not be a reason for preserving large scope of policy space and to use it on the preferential basis within bilateral trade agreements.

\section{Multilateral trade negotiations}

The multilateral trading system, as it is functioning today, is the result of the Uruguay Round of negotiations, which was concluded in 1994 and implemented during the period of next ten years. Since than, the increasing number of WTO members could not agree on modalities for further trade liberalization and strengthened trade rules. State leaders and heads of governments have continuously declared their political will to further liberalize the global trade and to conclude successfully the DDA Round of negotiations. But the political impetus proved to be insufficient in the moment when negotiators from all over the 
world tried to convert the words of politicians into agreement on offers and requests for the trade opening. It is evident that the issue of the policy space has become a crucial one.

Nowadays, the disagreement among members of the WTO could not been considered as simple disequilibrium between the trade interests of governments and their readiness for concessions in a demanded structure, as it was in the GATT period. Such imbalances were in general sooner or later solved. Since the 90ties, the WTO members face a new type of imbalances in their mutual relations, which became more obvious after the first phase of negotiations had been finished: even if it has not been officially acknowledged, many members have considered the requested restrictions of their policy space as a barrier to their domestic development and to their export expansion. In opposing the trade requests of others, they in fact defended their independence or high degree of freedom in their domestic policies.

This concept has been clearly evidenced during the period following the Ministerial Conference in Mexico in 2003, when members had been ready to continue negotiations only under a condition that some sensible - and never until negotiated - trade topics of the interest of developed countries were excluded from the mandate of negotiations (Štěrbová, 2007).

The current round of negotiations, Doha Development Agenda, started in 2001 as a comprehensive agenda for negotiations and future work of the World Trade Organization. The DDA has been intended to address specific issues of particular concerns to developing countries which were not met in the WTO agreements negotiated under the Uruguay Round. A list of "implementation" issues has been specified as issues to be renegotiated and eventually changed. Over all sections of the negotiations, the special and differential treatment should be considered in order to ensure preferential treatments or less than full reciprocity for developing countries in the future trade liberalization. Least developed countries are exempt from all liberalization commitments. Aid for trade, technical assistance and capacity building were approved to be the corner stones of the future development of global trade governance.

Nevertheless, the interests of developed economies have been also included into the mandate of negotiations. Since in global trade the tariffs are no longer considered to be insurmountable, the main obstacles to trade are tied to a large range of domestic policies rather than to the trade policy only - administrative procedures, (missing) competition rules, environmental protection, investment measures, government procurement, lack of the protection and enforcement of the intellectual property, etc. The obstacles to trade in domestic policies raise transaction costs, which are estimated to attain in individual cases up to $80 \%$ of the whole amount of the trade operation. The domestic policies could even exclude the trade or investment operations, namely if these policies are not set down in a transparent and predictable manner. The intention of developed countries has been to strengthen rules in areas related to trade and to pursue their interests in creating the high level conditions for production all over the world. The "same" conditions, reflecting for example environmental protection, intellectual property protection, transparent investment and competition rules, would from one side enable a deeper expansion of industry from developed countries, on other hand it would diminish the competition which is based on low production costs. Only such an exchange for future inevitable commitments in agricultural trade and respective domestic agricultural policies could have been advocated and "sold" to the industry groups and constituency in developed countries.

In my view, the problem lies in the specification of interests of developed countries, which has been developed in a very broad perspective. Not only the market access interests 
were specified within the trade in industrial goods and in services, but the requirements for rules improvement covered also areas, which were considered by developing countries as non-conceivable. Taking into account the obstacles of trade that are to be faced within other than purely "trade" areas, developed countries' approach (and the approach of their industry and businesses) seemed to be justified; it overwhelmed, however, the negotiation round and antagonized WTO members. Although approved by all, the negotiation framework from Doha reflected broadly the industrialised countries' consideration that their liberalisation regarding market access has almost reached its maximum limits and that the interest thus ought to be concentrated on advocating further liberalisation (at and within the borders) in developing countries.

\section{Prospects of multilateralism in trade governance}

In the multilateral trade negotiations, the antagonism among members and among group of members remains for a long period the same: the agriculture is considered as a heart of all negotiations for developing countries. In agricultural trade, they face a high level of barriers mainly in the fields of domestic supports and export subsidisation from industrialized members. For developed countries, the agriculture domestic policy is the only policy within which the influential lobbyist groups do not alleviate their integral pressure for protection from foreign competition. All other fields of negotiation, also difficult and controversial, are frozen and are waiting for the agriculture outcomes. Nowadays, three years after the original deadline of the 1 January 2005 for the current round of negotiations, the WTO members are not any closer to successful conclusion of the round as they were after the Cancún (Mexico) conference.

The negotiations are further complicated by the fact that members try to reflect in the negotiations not only their own trade interests, but also interests of the regional groups, to which they belong. Such an example is Mercosur, which forwarded a proposal for special exemptions in industrial products liberalization for this regional block.

The prospects of further multilateral liberalization are very difficult to anticipate. It is clear that WTO members prefer a substantive deal to any political declaration. It is a reason, why no ministerial conference happened in 2007, although the status of WTO stipulates that trade ministers meet at least once in two years. It seems however that with the prolongation of round, the substantive liberalization deal departs also due to the development in domestic policies of WTO members, which should be concerned by it. For example, the U.S. Congress is voting on a new farmer bill, which could for a long period constrain the U.S. government from cutting agricultural trade barriers. The EC is in a similar situation, although not officially acknowledged: the limits for agricultural trade liberalization, embedded in the "new" CAP (Common Agricultural Policy), could not accommodate all of the interests of developing countries.

Moreover, the negotiation procedure is very long, given the number of WTO members and the negotiation principles of consensus and single undertaking. Even after members would have agreed on liberalization modalities, they should translate them into commitment schedules. This process takes months. The domestic policies (elections, government crises) of the main trade leaders involve considerably the process, too. It is unlikely that a draft deal could be agreed upon at the beginning of 2008 before the U.S.' 2008 election campaign gets into full swing. But even if there is sufficient progress in the WTO in January or February next year - for example an agreement on the liberalization modalities - nothing could ensure that the George W. Bush administration obtains a "trade 
promotion authority" (TPA) from Congress ${ }^{1}$. In July 2008, France, which among EC countries always strongly opposes agricultural trade liberalization, will take over the presidency of the EU. If according to the domestic political development in the USA the Doha Round has to wait until 2009, it could be slowed down by the Indian elections due later that year.

Such political obstacles arise in all countries periodically - among 151 members it is very hard to identify the best period which could be classified as favourable to the deepening of the global trade governance and trade liberalization.

Despite the new framework of negotiations from July 2004, within which the extend of talks has been cut, negotiations are complicated by a large number of separate aspects within each field of negotiations - agricultural trade, industrial products, intellectual property, trade facilitation and rules for antidumping, subsidies. In agricultural liberalization, for example, the extent of subsidy reduction and market access expansion will depend on multiple sets of numbers and technical definitions, including the members' flexibility to shelter some "sensitive" farm products from the full force of tariff reduction in exchange for expanding import quotas. This tiny element requires one to consider the basis for the quota expansion (domestic consumption level or other) and to decide on methodologies for calculating consumption data and designating sensitive products. Only afterwards, could members develop a clearer picture of precisely what they stand to gain or lose taking into account the mentioned aspect and flexibility that offers.

The negotiation within the issue of regional trade agreements is not easy, too. The basis for regional trade agreements, provisions of GATT and GATS, is not clear enough. Explanation of the respective articles is a subject to long discussions. WTO members have not yet found, for example, a definition of "substantially all the trade", which is traded between parties to these agreements. In this area, however, WTO members consensually agreed the rules for transparency in these agreements (notification procedures), which were on the provisional basis approved by the General Council.

Notwithstanding, as the main question remains the domestic policies space, which each of the members would like to see as "protected" after the liberalization negotiations have been concluded. It has been once more proved in a joint statement of 15 November 2007 from the G-1102: : "Clarity about the actual contribution that will be made by developed countries will enable developing countries to do their part, in proportion with their capabilities and in line with the mandate." In this simple phrase, developing countries are asking for policy space release by developed countries, reserving by the same their flexibilities not to sacrifice their own.

\section{Dubious alternatives}

During last 10 years, preferential trade agreements (PTA), based on regional relations, continue to multiply and reach a high number. Objective reasons for this development are to be found in the multilateral trading system itself and in development of negotiations on trade liberalization. As mentioned before, WTO rules offer a large set of flexibilities, which allow exemptions even from the basic WTO principle on non-discrimination, which means

1 TPA allows the president to put trade deals to Congress for a yes-or-no vote without the possibility of amendments. Without the TPA the Congress could change already-finalised deals.

2 Group 110: the G-20, the G-33, the NAMA-11, the ACP group, the least-developed country (LDC) group, the African group, the small and vulnerable economies, and the so-called cotton four. The statement made at Geneva WTO meeting, referred by Bridges weekly, 22 November 2007. 
from the most-favoured-nation principle. These exemptions are based on GATT article XXIV and GATS article V, according to which the WTO members are free to conclude bilateral or plurilateral "integration" agreements on reciprocal trade preferences. Since the failure of the WTO Ministerial Conference in Seattle in 1999, members of the WTO have been facing the problem of how to respond to the demand of their industry to pursue their export and investment. The preferential agreements are more and more considered by governments as an alternative to the multilaterally binding system; this is why the mentioned provisions are widely used. The WTO estimates that the number of actionable free trade agreements exceeds 300, including agreements under negotiation and agreements which parties are not WTO members.

According to the opening statement of Director General of WTO, Pascal Lamy, at the the Conference on "Multilateralizing Regionalism" on 10 September 2007 in Geneva, the proliferation of PTAs is breeding concern - concern about incoherence, confusion, exponential increase of costs for business, unpredictability and even unfairness in trade relations. As he stated, many regional initiatives have made important contributions to economic welfare and doubtless to political stability as well. Questionable is the downside of an exponential expansion in regional trade agreements. He concluded the tangle of overlapping trade agreements will increasingly generate an interest in multilateralizing regional arrangements, in expanding them - or in other words, collapsing them into larger entities that bring governments much closer to a multilateral system of trade arrangements. He however raised a question what forces and interests might push trade relations in a multilateralizing direction.

We can analyze the set of preferential trade agreements of the main developed economic and trade leaders, the USA and EC, and try to respond to the question, if there is any attempt to multilateralizing regional trade arrangements, or if the bilateral agreements are considered to be an convenient alternative to multilateral agreements.

First, we should compare the official trade policy related to multilateral or regional agreements, and in a second stage, the practical outcomes. The political proclamations on the trade strategy of the US and of the EC are different, the basis for their arguments is however the same.

In the U.S. trade strategy, the regional trade initiatives are clearly stated as its key part. The reason is to open actively markets abroad and to meet the interests of some industry, like services and information technology. The market opening abroad, however, fear the reciprocity - opening of the U.S. market, loss of jobs, loss of government's subsidies, etc. These aspects could be more narrowly considered in bilateral agreements, than through the multilateral approach.

The U.S. regional trade initiatives include the Free Trade Area of the Americas aimed at uniting the Western Hemisphere in a free trade zone; the Enterprise for ASEAN Initiative, designed to promote trade in Asian countries; the Middle East Free Trade Initiative; and the North American Free Trade Agreement (Canada, Mexico). Since 2001, the U.S. completed and implemented free trade agreements with Israel, Chile, Singapore, Australia, Morocco, Bahrain, Jordan, Colombia, CAFTA-DR (El Salvador, Nicaragua, Honduras, Guatemala and the Dominican Republic) and has initiated FTA negotiations with Southern African Customs Union countries (Botswana, Lesotho, Namibia, South Africa, Swaziland), Korea, Colombia, Ecuador, Malaysia, Oman, Panama, Peru, Thailand and United Arab Emirates.

Although the U.S. trade strategy is based on preferential agreements, it is not obvious, that they are supported by domestic political leaders. Even if the free trade agreement with 
Peru has been voted in the Congress and is now subject to the same process in the Senate, it is not clear if the Congress proceeds to the pending three negotiated free trade agreements with Korea, Colombia and Panama. The three agreements have been languishing. The Korea deal, by far the most significant in commercial terms, is stuck over concerns about beef and auto trade; the Colombia one due to persistent concerns among Democrats about a history of high murder rates for labour leaders there. The Panama deal is blocked because the head of the country's parliament is wanted in the U.S. for the murder of an American soldier.

The European Communities declare a need for further multilateral liberalisation and a strengthening of the multilateral trade rules. For EC, multilateral agreements are the most effective means of managing trade for the benefit of all, keeping in mind economic growth, social cohesion and environmental protection.

Accordingly, the EC state to have subordinated their trade policy instruments and measures to the multilateral priority. The new bilateral or regional initiatives are used as complements only where appropriate and necessary. In their argumentation, EC propose a new generation of bilateral FTAs, which build on WTO rules and address issues which are outside of the scope of WTO agreements. Bilateral and regional agreements are considered to be a tool for the scope extension of trade liberalization and a way how to prepare the ground for the next level of multilateral liberalisation. From this point of view, free trade agreements support multilateral negotiations.

According to the official EC statement during the EC Trade Policy Review at WTO in 2007, the launching of new bilateral or inter-regional negotiations will complement the DDA and not interfere with it. The main criterion of the new agreements is market access; the expected results are a "topping up" of the substantial liberalisation that the DDA will achieve and not an alternative to it. Nonetheless, the decision by the EC to launch new free trade agreements negotiations was criticised by very many partners during the mentioned review as an impediment to the transparency of the EU trade regime.

If we analyze the EC regional and bilateral FTAs in depth, we recognize that the EC has confined the application of its exclusively most favoured nation (MFN) tariff to nine WTO Members. Even if their share of the total EU merchandise imports is big and accounted for some $30 \%$ of its total in 2005 , it means, that about $70 \%$ of EU imports is based on autonomous, unilateral, asymmetric or reciprocal preferences.

We can consider the broad geographical coverage of the EC's preferential trade arrangements to be a reflection of the global economic and trade reach of the EC. We should, however, analyze reasons and arguments which were the origin of these agreements. The conclusions are quite simple - in pursuing a trade expansion of its industry and investment, the EC is trying to find the most appropriate tool to create the most favourable conditions for its enterprises at foreign markets. As the multilateral negotiations on trade liberalization are not very promising, the EC found an alternative in free trade agreements. This alternative is justified by the situation in that enterprises from other countries are more competitive because of preferential entry conditions based on FTAs. This pragmatic approach is more than clearly proved by launching the negotiations on free trade agreement with Korea at the same time when it was sure that Korea is about to sign such an agreement with the U.S.

The EC has concluded 22 regional trade agreements with 24 countries and territories. Developing countries and least developed countries benefit from the Generalised System of Preferences and from the duty free and quota free access to the EC market (known as the 
„Everything-but-Arms” initiative). The EC's bilateral and bi-regional agreements extend beyond the scope of the WTO's agreements on liberalization and on trade rules.

From European countries, Norway, Iceland and Liechtenstein are associated with the EC's Internal Market through the European Economic Area (EEA). With Switzerland, a basis for mutual economic relations is established by trade agreement and other sector agreements. Stabilisation and Association Agreements are signed with the candidate countries Croatia, Macedonia and other Western Balkans countries. Candidate country Turkey is closely linked to the EC through a customs union. Free trade agreements are concluded also with countries of the EuroMed region (Tunisia, Morocco, Jordan, Egypt, Lebanon, Algeria, Israel, Syria and the Palestinian Authority). Comprehensive FTAs are in place with Mexico and Chile. The EC continues to develop its European Neighbourhood Policy with the Mediterranean countries (Maghreb, Mashrek and Israel), the three Western new industialised states (Ukraine, Moldova and Belarus) and the Caucasus (Georgia, Armenia, Azerbaijan). Also the Partnership and Co-operation Agreements or the Trade and Cooperation Agreement with Russia, Ukraine, Armenia, Azerbaijan, Georgia, Kazakhstan, Kyrgyzstan, Moldova, Uzbekistan and Mongolia have preferential trade aspects. Since the last EC trade policy review, negotiations with Mexico started under the Agreement's review clause on agriculture, services and investment.

The negotiations on free trade agreements are prepared or were launched with MERCOSUR, the Cooperation Council for the Arab States of the Gulf, Central American region, the Community of Andean Nations, Iraq, Iran, South Korea and with the 79 African, Caribbean and Pacific countries (ACP). The feasibility of an EC-ASEAN free trade agreement is examined. The dialog with other countries, for instance USA, Australia, New Zealand, Japan, Canada, China, India, includes also trade issues and some sector agreements has been signed as a result of it (agreements on wines with Australia and New Zealand, on textiles with China, etc.).

The PTAs of the US and the EC have the same features: the discrimination inherent in them is viewed favourably by interest groups that benefit from it. The same conclusion is valid also for preferential trade agreements of other states. If the latter interests prevail, we may expect continuing pressure upon governments to establish more preferential agreements and to defend existing ones against greater inclusiveness. The problem is that forces and interests might push in the contrary direction. In these cases, the effects of preferential agreements on trade opening and on the creation of new economic opportunities could be counterproductive.

\section{Conclusion}

The dialectics of global trade governance have manifested themselves in a broad manner during the three last decades, namely during the Uruguay Round negotiations on trade liberalization. It became more pertinent to the current negotiations, the Doha Development Agenda. The long and unsuccessful process and the discussion among WTO members could evidence that global trade governance, which is based on the multilateral trading system, exhausted its potential for supporting the trade expansion and economic growth.

The mentioned tendencies are proved by the practices of the main trade world leaders, the U.S. and the EC, which are concentrated on finding alternatives to the multilateral trade liberalization. These two countries approved and implemented in the last period very many free trade agreements, many others are under negotiations. The proliferation of free trade 
agreements is evidenced worldwide - they created a dense and complex network of different preferences and business conditions, which are very difficult for exporters to be acquainted with. This network undermines the transparency and non-discrimination principles, which are the basis of the global trade governance, and divert interest in the multilateral trading system. As a result, the network of free trade agreements creates an obstacle to the free trade.

The concept of regionalism which is a first step to multilateralism and to the global trade governance is widely discussed. Some academics elaborate more and more frequently the idea that the regional trade governance, once it is put in place, could be extended to global trade. I would disagree firmly with them. This hypothesis is to be refuted by two arguments: first, the extension of the regional integration into global trade will concern all participants, because of the erosion of preferences which they enjoy in their regions or within preferential agreements and which allowed them to exclude their competitors from the target markets. Second, the evidence from multilateral discussion proves that regional integration on the level of free trade agreements brings into negotiations new aspects as the countries should take into account in liberalization also trade and political interests of their "closer" trade partners. These new aspects are also a reason why WTO members remove significantly from the final substantive deal.

In trade governance, if it should be the global one, regionalism shall not be prevailing. Not only the existence of very many preferential trade arrangements creates a non-transparent environment, but it leads governments to preserve their policy space in a larger extend, in order to be able to offer part of it in exchange for trade preferences in the framework of eventual future FTAs. This tendencies are further strengthened by the fact, that preferences enjoyed by foreign competitors at foreign markets are compensated to domestic industries by higher protection, which aim is to create economic "survival" conditions and to preserve job positions, because the industries are not able to compete abroad due to discriminatory "preferential for others" environment.

In my view, global trade governance could be strengthened only if the governments of the leading traders give up their policy space in favour of free trade and its global (international, not supranational) governance. The effects of preferential trade agreements are ambivalent; these agreements may adversely affect the welfare of non-members due to trade diversion. Regionalism is not an alternative to multilateralism, it is not even supportive to it and it does not create a building block for the global governance of trade. On the contrary, regionalism, in the extend we witness it in the most recent period, undermines global trade governance. I conclude that the prospects for multilateralizing regionalism are very weak. 


\section{References}

BRIDGES Weekly (2007). 5 December 2007. http://www.ictsd.org/weekly/index.htm.

HASTEDT, G. P. (1999). American Foreign Policy - Past, Present, Future. New Jersey, Prentice Hall, p. 276.

KRUGMAN, P. R.; OBSTFELD, M. (2006). International Economics: theory and policy. Pearson International Edition.

ŠTĚRBOVÁ, L. (2001). Aktuální otázky Světové obchodní organizace. Praha, VŠE.

ŠTĚRBOVÁ, L. (2007). Současné tendence a změny ve společné obchodní politice EU. In Proceedings from 7th international scientific conference "The Czech and Slovac Republics in International Business". Bratislava, pp. 276-286.

ŠTĚRBOVÁ, L. (2007). WTO-Davos: Jednání o mezinárodním obchodu se toči dokola. http://www.blisty.cz/2007/1/30/art32591.html.

Financial Times (2007). 3 December 2007. http://www.ft.com/cms/s/0/6910a18c-a142-11dc-9f340000779fd2ac.html?nclick_check=1.

WTO (2007). WT/TPR/G/177 Trade Policy Review - Report by the European Communities. Geneva, WTO.

WTO (2007). World Trade Report.

http://www.wto.org/english/res_e/reser_e/.

WTO (2007). WTO Annual Report.

http://www.wto.org/english/res_e/booksp_e/anrep_e.

WTO (2007). Speech of Pacsal Lamy: Proliferation of regional trade agreements "breeding concern".

http://www.wto.org/english/news_e/sppl_e/sppl67_e.htm.

WTO (2007). WTO forum, 8 November 2007. http://www.wto.org.

USTR (2007). United State Trade Representative Office, Trade Agreements. http://www.ustr.gov/Trade_Agreements/Section_Index.html. 


\title{
Může být regionální obchodní integrace stavebním kamenem celosvětového řízení obchodu?
}

\author{
Ludmila Štěrbová
}

\begin{abstract}
Abstrakt
Některé teoretické směry se zabývají možností multilateralizace regionálních přístupů a vybudování celosvětově fungujícího systému pravidel na základě regionalismu. Tyto tendence se promítají i do oblasti mezinárodního obchodu. Základním problémem mnohostranného obchodního systému, zastř̌ešovaného Světovou obchodní organizací, je však rozsah politického prostoru, kterého se vlády států nechtějí vzdát ve prospěch celosvětového řízení obchodu. I když v současné době mnohostranný obchodní systém a další mnohostranná liberalizace obchodu čelí řadě překážek, regionalismus není alternativou, která by pomohla státům prosadit jejich obchodní zájmy. Naopak, bilaterální preferenční obchodní dohody poškozují ve svém důsledku hospodářskou soutěž, zkreslují obchodní prostředí a podkopávají mnohostranný obchodní systém.
\end{abstract}

Klíčová slova: mnohostranný obchodní systém; preferenční obchodní dohody; politický prostor.

\section{Could Regional Trade Integration be a Building Block for Global Governance of Trade?}

\begin{abstract}
Some theories consider the possibility to multilateralize regional approaches and to establish global system of rules based on regionalism. These tendencies are also tailored on international trade. Nevertheless, the fundamental problem of the multilateral trading system in the framework of the World Trade Organization is the extent of policy space, which states' governments do not want to give in favor of global trade governance. Although the multilateral trading system and further multilateral trade liberalization face many challenges, regionalism is not an alternative that could help government to pursue their trade interests. On the contrary, bilateral Preferential Trade Agreements harm competition, distort business environment and undermine the multilateral trading system.
\end{abstract}

Key words: multilateral trading system; Preferential Trade Agreements; policy space.

JEL classification: G30 